Canadian Journal of Higher Education

Revue canadienne d'enseignement supérieur

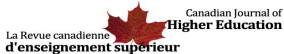

\title{
Book review of "Handbook of Canadian Higher Education Law"
}

\section{Tamara Leary}

Volume 47, Number 3, 2017

URI: https://id.erudit.org/iderudit/1043247ar

DOI: https://doi.org/10.7202/1043247ar

See table of contents

Publisher(s)

Canadian Society for the Study of Higher Education

ISSN

2293-6602 (digital)

Explore this journal

Cite this review

Leary, T. (2017). Review of [Book review of "Handbook of Canadian Higher Education Law"]. Canadian Journal of Higher Education / Revue canadienne d'enseignement supérieur, 47(3), 200-202. https://doi.org/10.7202/1043247ar

Copyright (c) Tamara Leary, 2017

Attribution-NonCommercial-No Derivative Works 2.5 Canada
This document is protected by copyright law. Use of the services of Erudit (including reproduction) is subject to its terms and conditions, which can be viewed online.

https://apropos.erudit.org/en/users/policy-on-use/ 
Canadian Journal of Higher Education Revue canadienne d'enseignement supérieur

Volume 47, No. 3, 2017, pages 200 - 202

\title{
Book Review / Compte rendu
}

\author{
Shanahan, T., Nilson, M., \& Broshko, L.J. (Eds.) (2015). Handbook of Ca- \\ nadian Higher Education Law. Kingston, Ontario: Queen's Policy Studies. \\ Pages: 390. Price: 39.95 CDN (paper).
}

Reviewed by Tamara Leary, Associate Professor/Program Head, Royal Roads University

The editors of Handbook of Canadian Higher Education Law are to be commended for having addressed a gap within Canadian higher education literature. Each of the 12 book chapters is written by an experienced subject matter expert from the higher education and/or legal sectors.

The book is divided into four parts. Part 1, comprised of three chapters authored by one of the book's editors, Theresa Shanahan, offers a comprehensive overview of the history of Canadian higher education organization and governance. Attention is given to the uniqueness of our sector, given our country's evolution. Prior to Confederation, the development and delivery of education was led by the Christian church. Church leaders in each of the four original provinces - Ontario, Quebec, Nova Scotia and New Brunswick - ensured that religious denomination and language (French or English) were foundational in educational institutions. Maintaining control over education was something provincial leaders would not waver on, and to move forward with Confederation, "the Fathers of Confederation' conceded to colonial leaders the preservation of the existing provincial education systems" (p. 4). To this day, education is recognized as the responsibility of each province and territory, and there is no federal governing body for education in Canada. By detailing the history of higher education, the author provides the reader an understanding of how the legislation governing higher education institutions is specific to each province; there is a chart in the appendix that details the provincial regulation of post-secondary education in Canada. Shanahan concludes Part 1 by highlighting the challenges for institutions and governments to effectively respond to ever-increasing societal expectations and needs, given the variations in higher education legislation and regulations across the country and even within provinces.

Part 2 of the book provides an in depth look at legislation that applies to each of the following topics: governance of institutions, human rights issues applicable to institutions as employers, and associations aligned with specific higher education stakeholder groups (ac- 
ademic, faculty, student and athletic). Each chapter cites examples of case law to illustrate how legislation has been applied to issues pertaining to each topic. Chapter four details the power, roles and limitations of each of the positions and stakeholder groups (chancellor, board of governors, senate, president and vice chancellor) that together are responsible for the overall governance and operations of an institution. The author references the outcome of specific cases as examples of conflict between the governing positions and groups. Chapter five discusses the variations in human rights legislation across Canada. While all institutions have legislation that prohibits discrimination on proscribed grounds, what is defined as "proscribed" can vary between jurisdictions (p. 83), which means that what is a human rights issue in one institution in one province may not necessarily be so in a different institution and province. The rights of students and responsibilities of institutions in: student admissions; curriculum requirements and testing; and learning disability accommodation (p. 104) are identified and examples of case law are provided. Chapter six offers a high-level look at the few associations that influence institutional governance as well as policy and legislation. In the absence of a federal accreditation body or authority, institutions in Canada are left on their own to orchestrate associations through which standards can be established and enforced. The authors reference: Universities Canada, recognized nationally as a leading voice within higher education yet has only 97 institutional members; the U-15, an association restricted to 15 self-described "research intensive" institutions; the Alliance of Canadian Comprehensive Research Universities (ACCRU) made up of smaller research institutions excluded from the U-15; and the U-4, which has a membership of 4 small non-research focused institutions that seek to develop teaching and learning practices as well as identify research opportunities and partnerships. The point made by the authors is that, yet again, Canadian higher education is in many ways more divided than united - emphasizing the points made in earlier chapters about the fragmented and complex nature of the sector in Canada.

Part 3 explores the contractual relationship between an institution and the students (Chapter seven) and an institution and its faculty (Chapter eight). Chapter seven describes how the institution's duty of care for students has evolved. For years institutions had full authority and autonomy over how student behavior was dealt with; this is no longer the situation. The authors highlight issues and case law relevant to student privacy, student discipline, intellectual property, and human rights that require clarity on the part of both the institution and students about the rights and responsibilities of each, and on due process. Chapter eight presents the legal framework for faculty employment in Canadian higher education. The implications of union contracts and the uniqueness of employment terms such as "academic freedom" and "tenure" contribute to what can be complex and trying matters for faculty, institutions and the courts. The authors offer examples of case law to help explain this complexity.

The final part of the book explores, from a legal perspective, higher education institutions' relationships with the community. Chapter nine focuses on intellectual property - the ownership and copyright over what is produced during employment with an institution. With increased calls from community and government for accountability on how taxpayers' money is utilized, institutions have had to take a closer look at not only who owns intellectual property but how it can be leveraged and by whom. Chapter ten develops ideas presented in chapter nine about intellectual property, the commercialization 
of research and knowledge mobilization. These are relatively new issues for Canadian institutions and, accordingly, there is less case law offered as evidence of legislation being applied to these types of issues. The need for continued partnership and conversation between institutions, researchers, government and industry is paramount. Chapter 11 delves into the land development rights and responsibilities of an institution. Whether an institution is looking to acquire, dispose of or develop land the transaction may be subjected to regulatory process depending on the type of institution, the nature of the request and the provincial or territorial legislation. The implications of land ownership or transactions are also discussed: property tax law; land development law; and the impact on an institution's charitable status.

In the final chapter of the book editor Michelle Nilson offers a succinct summary of each of the book's parts and identifies emerging issues for each topic area. This book is a good resource for scholars, practitioners, and leaders within Canadian higher education. If the chapters are read in numerical order there is repetition among them on the origins of the sector and its complexity, and on reoccurring topics such as academic freedom, intellectual property, human rights, and governance. What is evident throughout the book is how the once assumed autonomous position of a higher education institution, particularly a university, is being challenged on all fronts. Public accountability, students' rights and voices, and demands for transparency have all contributed to an increasing interest in and need for clarity on what and who governs the operations, decisions, policies and protocols of higher education institutions in Canada. This book addresses those questions and offers a well informed and balanced perspective in doing so.* 